\section{Recent inactivity in African rift}

SIR - Within the past decade, global positioning geodesy (GPS) has been aimed at a host of tectonic targets ranging from volcanic and seismic hazards to plate motions and global sea-level studies $^{1}$. These experiments typically reward their investigators when signals emerge above the 1-cm uncertainty commonly associated with GPS data. Thus plate-motion studies gain credibility after a few years of measurement, global sea-level studies after perhaps a few decades, while volcanic eruptions and earthquakes yield reportable results as and when they occur within existing geodetic networks. In short, geophysicists have set their GPS nets and now wait for the Earth to move.

Tectonic passivity is rarely of note. Yet in zones where dramatic volcanotectonic architecture was formed yesterday, geologically speaking, the exception becomes interesting. The current widening rate of the East African rift has been estimated by various authors at 3-8 $\mathrm{mm}$ per year based on differing geological reconstructions ${ }^{2}$. Sinistral shear amounting to $50 \%$ of the opening rate has also been proposed (ref. 3 and W. Hay, personal communication). Between 1969 and 1976, one of us (P. M.) installed networks of geodetic stations across the Ethiopian rift, including one near Addis Ababa ${ }^{4}$. Inter-station distances of up to $20 \mathrm{~km}$ were measured with an accuracy of $0.5-1 \mathrm{~cm}$ using a Mark 8 geodimeter. In January 1992 we remeasured some of these lines using GPS technology with a similar accuracy. (GPS data were obtained at 15 -s intervals in three 5-h sessions using dual-frequency receivers. Processed data using precise orbits provided by Y. Bock yielded horizontal and vertical repeatabilities of \pm 1 $\mathrm{cm}$ and $\pm 2.5 \mathrm{~cm}$, respectively.) Astonishingly, the three long lines that we recovered, spanning $46 \mathrm{~km}$ of the $90-\mathrm{km}$ width of the northern Ethiopian rift, yielded data agreeing with the geodimeter data within their respective experimental errors. The data indicate a total widening of this part of the rift by 1 $\pm 2 \mathrm{~cm}$ in 20 years, or a net widening rate of $0.5 \pm 1 \mathrm{~mm}$ per year. Were this rate uniform across the whole width of the rift at this latitude, the maximum widening rate would be $1.1 \pm 2.2 \mathrm{~mm}$ per year, much lower than any previous geological estimate.

Although convergence is permitted by the data, we consider this unlikely. Several stations on the western margin of the rift were not recovered, and many lines are yet to measured, but those that were remeasured embrace the central most active part of this sector of the rift valley. The data imply extensive strain of

LGM, last glacial maximum.
$10 \pm 20$ nanostrain per year, an unexpectedly low strain rate for this neo plate-boundary. Episodic rifting is therefore implicit in relating our results to the manifest youthfulness of the rift faulting/ fissuring ${ }^{5,6}$. If strain rates are uniform in time, and if tensile failure occurs near 10 ustrain, we should not expect episodes of rifting to occur more frequently than every 3,000 years in the Addis sector.

We are reminded that, in 1932, students of Alfred Wegener installed a geodetic network spanning the Krafla dike injection zone in northern Iceland, which when remeasured in 1956 revealed no deformation ${ }^{7}$. The students' prescience was rewarded in 1975 when $8 \mathrm{~m}$ of widening occurred within their network ${ }^{8}$. East African rift activity is slower than in

\section{Carbon stores in vegetation}

SIR - Analyses of fossil pollen and plant macrofossils in sediments and packrat middens show that the American southwest has undergone extensive vegetational change since the last glacial maximum (23,000-17,000 years ago) from an area mostly dominated by woody vegetation to the deserts and arid grasslands of the present ${ }^{1}$. Using maps published by Martin and Mehringer and estimates of carbon storage (see table), we have calculated that this vegetational change resulted in a decrease in carbon in vegetation of $12.3 \times 10^{12} \mathrm{~kg}$ over the $982,000-\mathrm{km}^{2}$ study area. The change in total carbon storage of this area, however, was virtually nil, due to the accumulation of large amounts of carbonate

in arid soils (see table). The shift in vegetative cover from forest to desert simply changed the form of carbon storage - from organic carbon stored in biomass to carbonate-carbon stored in soils.

Although deserts have expanded in the American southwest since the last glacial maximum, on most other continents the area of desert land has contracted. Adams et al. ${ }^{2}$ reported that there has been a global decrease in the area of deserts and, therefore, an increase in carbon storage in vegetation and soils since the last glacial maximum. But a comparison of their data for soil carbon storage in temperate desert $(3 \mathrm{~kg}$ $\left.\mathrm{m}^{-2}\right)$ and semi-desert and dry steppe (6

AREAS AND CARBON STORAGE FOR VEGETATION TYPES

\begin{tabular}{|c|c|c|c|c|c|c|c|c|c|}
\hline \multirow[t]{2}{*}{ Area $\left(\times 10^{11} \mathrm{~m}^{2}\right)^{1}$} & $\begin{array}{l}\text { LGM } \\
\text { Present }\end{array}$ & $\begin{array}{l}0.36 \\
3.62\end{array}$ & $\begin{array}{r}0 \\
3.23\end{array}$ & $\begin{array}{r}0.87 \\
0\end{array}$ & $\begin{array}{l}2.17 \\
2.10\end{array}$ & $\begin{array}{l}4.84 \\
0.70\end{array}$ & $\begin{array}{l}1.40 \\
0.16\end{array}$ & $\begin{array}{l}0.18 \\
0.01\end{array}$ & $\begin{array}{l}9.82 \\
9.82\end{array}$ \\
\hline & Change & +3.26 & +3.23 & -0.87 & -0.07 & -4.14 & -1.24 & -0.17 & \\
\hline \multirow{4}{*}{$\begin{array}{l}\text { Carbon storage } \\
\left(\mathrm{kg} \mathrm{C} \mathrm{m}^{-2}\right)\end{array}$} & Vegetation $^{4,5}$ & 0.3 & 0.3 & 2.3 & 1.5 & 15.0 & 46.0 & 21.0 & \\
\hline & Soil-organic ${ }^{3}$ & 2.2 & 7.3 & 5.2 & 7.6 & 7.6 & 7.6 & 7.6 & \\
\hline & Soil-carbonate ${ }^{3}$ & 31.0 & 22.3 & 0.3 & 5.0 & 5.0 & 5.0 & 5.0 & \\
\hline & Total & 33.5 & 29.9 & 7.8 & 14.1 & 27.6 & 58.6 & 33.6 & \\
\hline \multirow{4}{*}{$\begin{array}{l}\text { Carbon storage, } \\
\text { vegetation only, } \\
\text { entire study area } \\
\left(\times 10^{12} \mathrm{~kg} \mathrm{C}\right)\end{array}$} & LGM & 0.01 & 0 & 0.20 & 0.33 & 7.26 & 6.44 & 0.38 & 14 \\
\hline & Present & 0.11 & 0.10 & 0 & 0.32 & 1.05 & 0.74 & 0.02 & \\
\hline & Change & +0.10 & +0.10 & -0.20 & -0.01 & -6.21 & -5.70 & -0.36 & -12 \\
\hline & Change (\%) & $+1,000$ & - & -100 & -3 & -86 & -89 & -95 & \\
\hline \multirow{4}{*}{$\begin{array}{l}\text { Carbon storage, } \\
\text { vegetation+soil, } \\
\text { entire study area } \\
\left(\times 10^{12} \mathrm{~kg} \mathrm{C}\right)\end{array}$} & LGM & 1.21 & 0 & 0.68 & 3.06 & 13.36 & 8.20 & 0.61 & 27.1 \\
\hline & Present & 12.13 & 9.66 & 0 & 2.96 & 1.93 & 0.94 & 0.03 & \\
\hline & Change & +10.92 & +9.66 & -0.68 & -0.10 & -11.43 & -7.26 & -0.58 & +0.5 \\
\hline & Change (\%) & +902 & - & -100 & -3 & -86 & -89 & -95 & \\
\hline
\end{tabular}

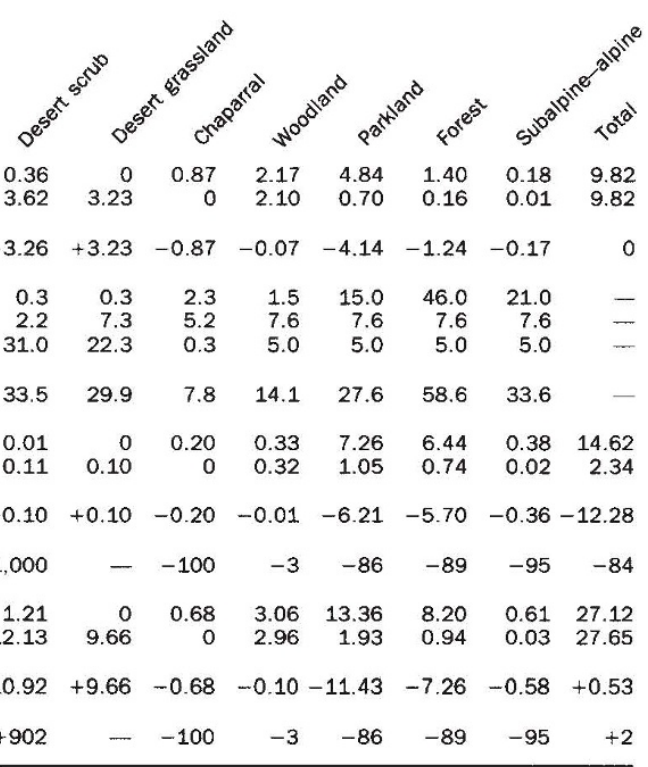

